\title{
Population Development and the Public Sector Economy in Finland
}

\author{
REINO T. HJERPPE
}

Director General

Government Institute for Economic Research

\section{KARI SUMMANEN}

Senior Research Officer

Government Institute for Economic Research

Väestöliitto has newly published a book dealing with the effects of current population trends on society and the life of the common people. The aim of Väestöliitto is to use this book to begin a discussion on population questions and to direct attention to the necessity for planning authorities and decision makers to take demographic aspects into consideration in their work.

The book discusses the effects of population aging on the public economy, education, industry and commerce as well as on the economy of the municipalities. We are here reproducing an article concerning the effects of population aging on the public economy and social expenditures. In economic theory population trends are considered exogenous, or factors outside the economic models. The authors, both economists, examine the link between population development and economy, mainly the public economy. They also discuss possible ways to avoid unwanted economic development caused by population aging. We feel the article might also interest readers outside the Finnish borders.

\section{Introduction}

The image formed by Europe's population has been revolutionalized after the end of the 1960s. In almost all the countries on our continent, the decline in fertility, which began with the industrial revolution, accelerated after the mid-1960s.

The impact of future population development is one of the most important reasons for discussing the crisis of the welfare state, which seems to be threatening us especially in the growth of the public sector.

Population raises several questions concerning public finance. First, how will population development affect the development of public finance, in general? How will public expenditures develop? What will happen to income, or in plainer terms, to the tax burden? What problems regarding planning and policy will the balancing of public finance be confronted with? These questions are very closely involved with the development of the entire national economy.

Secondly, we can ask what the government should do, if we feel that population development should be influenced more actively. If we want control over population development, we must know how measures taken by the government influence it, in general. What effect have they had earlier? Are there any methods available that can still be used in the future? 
As public action, family policy has customarily been considered primarily a means of influencing fertility. People feel that low fertility is a consequence of the weak status in society of families with children and young families, in general. The recent economic-theory approach in studying the causes of fertility provides us with the tools and reasons for analyzing this view more closely.

Low fertility is, in very many ways, related to the nature and structure of the welfare state. In modern industrialized countries, the conditions governing fertility behavior differ from what they used to be in earlier forms of society. Nevertheless, it appears that economic factors have always held a large and crucial role, when people are deciding about having children.

According to the economic-theory model, fertility is influenced, on the one hand, by values and benefits, and on the other, by economic restrictions and the possibilities for choice. In principle, the state can have an effect on the income available to households, and by that means, on their interest in having children. On the other hand, it is not at all clear how state policy could permanently lead to the emergence of family policy values.

The problem of population development is reflected in the economy, as a whole, as pressure toward increasing public finances. The long-term commitments of current social policy will automatically lead to this situation. Fulfilling these commitments will require continuous growth of the economy also in the future, when the labor supply starts to decrease. Fulfilling these commitments will also require more personnel for the public sector, in order to provide continuously increasing services. This may prove to be quite a problem, when the growth in the labor supply slows down during this decade and ceases altogether at the turn of the century.

At present, Finland has no official population goal that would express political stands on the development of the total population, fertility and immigration. Population development is considered a given factor in the various planning systems and studies carried out in the public sector. Very little assessment has been made of the impact of different measures on population development.

\section{Public finance and population development in the $1960 \mathrm{~s}$}

\section{The supply and demand of »population-policy» expenditures}

The public sector has grown rapidly during the last three decades. While total public expenditures made up 26.5 percent of the gross domestic product in 1960, in 1985 it rose to 44.6 percent. Here, statutory private employment pension insurance is also included in total public expenditures. The increase in the supply of so called welfare commodities accounts for 90 percent of the growth in the share of total public expenditures. Welfare commodities arise from welfare services and social security. Welfare services include social and health services and education services.

In 1960 social expenditures, which can primarily be considered »population-policy» expenditures, totaled 9.2 percent of the gross domestic product and more than onethird of the total public expenditures. ${ }^{1}$ In 1985 their share of the gross domestic

1 Social expenditures here include pensions, health insurance, unemployment security, accident insurance, military injury insurance, family security, other income security, social services and health services. In this article, social expenditures are called »population-policy» expenditures because their problems are most frequently linked with population development in general discussions. Later we will demonstrate the need for an analysis of the effects of population development on public finance, encompassing more than just the development of social expenditures. The primary source of the analyses in section 2 is Palm's (1988) study. 
product was 22.5 percent, equaling over one-half of the total public expenditures. In public finances, the inner structure of expenditures thus seems to be weighted more toward "population policy» than before.

In simpler terms, the development of public social expenditures can be seen to be caused by demand factors coming from households and supply factors and decisions coming from the state. Population development is a structural demand factor affecting the development of public expenditures. The supply and demand of public expenditures is balanced on »the political market», meaning in budget proceedings, and not on the usual commodity market, as in the case of the supply and demand of private consumer commodities.

On most markets, the interaction between supply and demand is not unilateral. Supply can also create demand. This happens especially with social expenditures. The expansion of the supply of health services has increased the lifespan, which, in the long run, will increase the demand for services and pension expenditures, for example. A population's level of education can also often be considered a factor directing demand.

Population factors explain the development of different social expenditures in different ways. According to Palm (1988), less than one-half of the actual 10-fold increase since 1960 in old age pension expenditures can be explained by the growth of the older age groups. The rest is due to the rise in the level of benefits, for example, with the growth in the number of better employment pensions. The rise in the level of benefits is mainly due to the development of social security. In Finland, the proportion of the population over the age of 65 has more than doubled since 1960 .

In reality, the total amount of family expenditures changed from 1960 to 1985 at the same rate as the change in the size of the target population. This means that, during this period, the population structure almost entirely explains the development of these expenditures. On the other hand, it also means that the actual level of family security benefits in 1985 was almost the same as in 1960 - after the recession which continued into the early 1970 s and the reforms implemented from 1974 on. The target population of family security has shrunk about one-third since 1960 .

Only a small portion of the increase in work disability pension expenditures and unemployment security expenditures is caused by the aging of the population structure. The same is true of the development of total expenditures for social and health services. Increased access explains one-half and the rise in costs per unit about 40 percent of the growth in public expenditures allocated to services.

The aging of the population is strongly increasing the demand not only for pensions but also for health services. This demand is being increased especially by the growth of the oldest age groups.

\section{Social expenditures and the state budget}

The growth in social expenditures has been reflected in the state budget especially as an increase in transferred expenditures. In 1970 transferred expenditures totaled 45 percent of all state expenditures. In 1985 they had grown to over 52 percent and will rise to 64 percent in the 1990 budget. These figures also include transferred expenditures allocated to industries. The most rapid increases in transferred expenditures have occurred in state subsidies and grants to education, social and health services and social security.

Altogether, the state expenditures on direct income transfers to households have grown more slowly than these income transfers have as a whole. For example, while pension expenditures, in reality, grew four-fold during the last two decades, the state's 
expenditures on pension security grew three-fold. The reason for this is, naturally, that private pension insurance companies are providing for this rapidly developed pension security. Half of the pension expenditures affecting the state budget are the state's own unfunded pensions. The rest consist of subsidies paid by the state for funding national pensions and pension expenditures for agricultural entrepreneurs, other entrepreneurs and seamen and of front-veteran's pensions.

In the long run, the primary source for public income is taxation. In 1960 the gross taxation level of the national economy, the percentage made up by all taxes, was 25 percent. Today the gross tax level is 37.5 percent. However, one should bear in mind that statutory earnings-related pensions are funded in the private sector with obligatory social security payments. On the international scale, a more correct picture of Finland's tax burden is provided by the total taxation level, which includes these payments. The total taxation level is currently 42 percent.

In the mid-1970s the income tax burden increased, when the state income tax scales had not been adjusted for several years in regard to inflation and income development. The resulting increase in tax income improved the situation of the state economy and helped make it possible to fund intensified family policy measures in the 1974 income policy agreement. In the period of revival at the end of the 1970s, limits were set to the growth of the public sector, when economic policy measures were being taken to check inflation and improve our ability to compete internationally. This also delayed the development of social policy.

In the early 1980 s, several social policy reforms were implemented which increased social expenditures: a national pension reform, a substantial increase in the per diem allowance for sick leave and parental leave in conjunction with their coming under taxation, a subsistence security reform and an unemployment security reform. In addition, the supply of children's day care was increased.

\section{The income-transfer society and housoholds}

In the development of a welfare state, we can also speak of the birth of an income-transfer society, cf. Hjerppe (1986). For example, when twenty years ago about 16 percent of disposable household income came from income transfers from the public sector, today the proportion is already 33 percent. In the long run, the development of welfare expenditures has contributed to equalizing the distribution of income, which is considered one of the central factors affecting the welfare of the population (Figure 1).

Public subsidies to households are not confined to income transfers, however. In practice, services which are often free-of-charge or cost only a fraction of actual expenses markedly increase the actual total income households have at their disposal. The taxation system contains considerable indirect support in the form of various deductions, exemptions and the equivalent, which cannot be seen in regular budget and statistical figures. Child deductions, for example, are clearly meant as family policy support. Pension income deductions are an extension of pension security. State housing loans are also subsidized, as their interest rate is, on the average, clearly less than the market interest rate.

State expenditures to households are examined in Table 1. The public sector has a greater effect on population development through indirect support than through social expenditures. Tax supports are especially significant in housing policy, in equalizing family expenditures and in health care and in caring for the ill. Cost-free service benefits are especially pronounced in education and health care policy. They 
Figure 1. Distribution of disposable household income in 1966 and 1985.

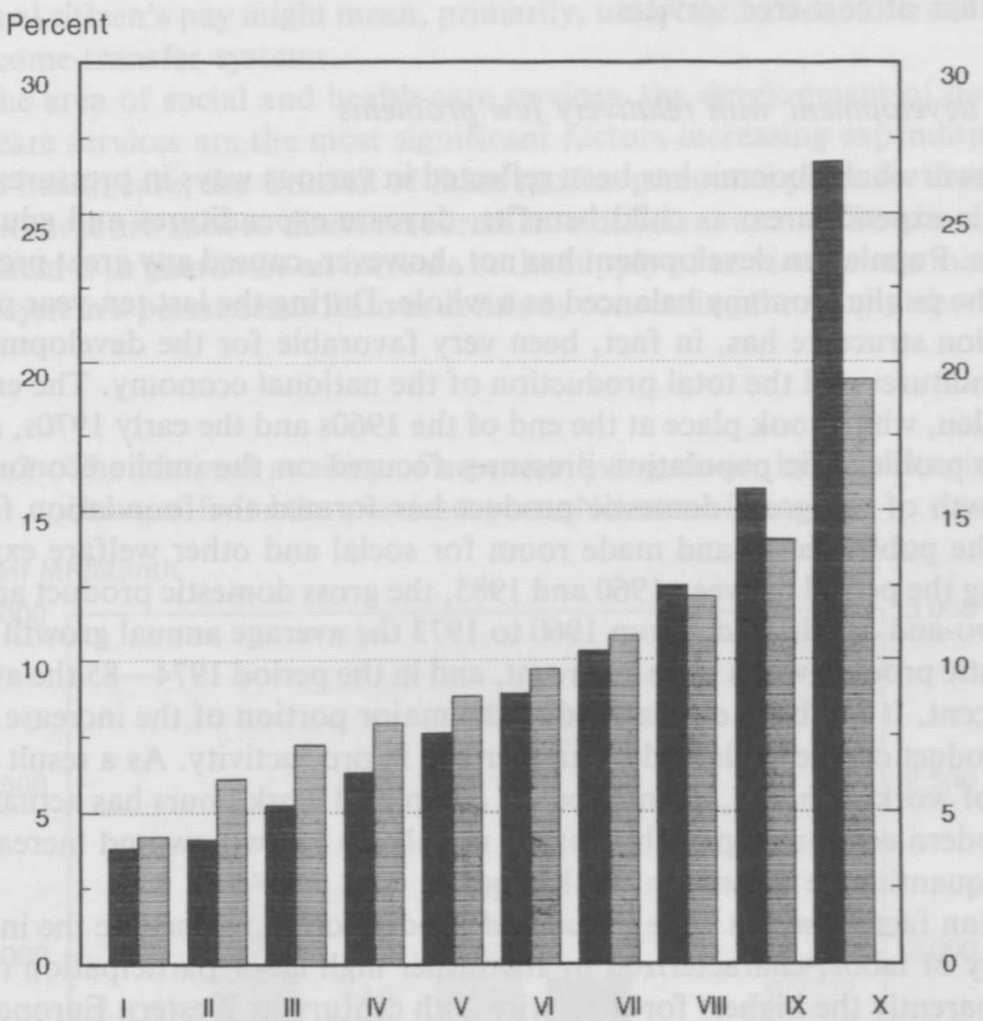

HOUSEHOLD DECILE

Disposable income per person

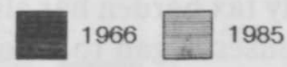

Source: Uusitalo 1988.

Table 1. State expenditures on income transfers to households and state indirect subsidies to households in 1987 , in millions of marks.

$\begin{array}{cccc}\begin{array}{c}\text { Expenditures } \\ \text { on income } \\ \text { transfers }\end{array} & \begin{array}{c}\text { Expenditures } \\ \text { on cost-free } \\ \text { service } \\ \text { benefits }\end{array} & \begin{array}{c}\text { Tax supports } \\ \text { in state }\end{array} & \begin{array}{c}\text { Financing } \\ \text { support }\end{array} \\ 22,200 & 29,200 & 9,900 & 1,600 \\ (70,300) & (50,200) & (16,400) & (1,700) \\ 6 & 7 & 3 & 1 / 2 \\ (18) & (13) & (4) & (1 / 2) \\ 20 & 26 & 9 & 1 \\ 10 & 14 & 5 & 1 \\ (33) & (23) & (8) & (1)\end{array}$

State total

expenditures) $)^{1}$

$\%$ of GDP $(393,500)$

$\%$ of final total

of budget $(111,060)$

$\%$ of disposable house-

hold income $(214,500)$

(23)

(8)

'Includes state, municipal, The Social Insurance Institution's and statutory pension insurance and unemployment security (benefits).

Source: Ministry of Finance Planning Secretariat 1986-89 and TMAE 1990, Appendix 3. 
are also significant in equalizing family expenditures. Pension security is dominated by income transfers, while in family security the role of income transfers is comparable to that of cost-free services.

\section{Population development with relatively few problems}

The postwar »baby boom» has been reflected in various ways in pressures bearing on public expenditures: as child benefits, daycare expenditures and education expenditures. Population development has not, however, caused any great problems in keeping the public economy balanced as a whole. During the last ten-year period, the population structure has, in fact, been very favorable for the development of public expenditures and the total production of the national economy. The emigration to Sweden, which took place at the end of the 1960s and the early 1970s, solved some of the problematic population pressures focused on the public economy.

The growth of the gross domestic product has formed the foundation for the growth of the public sector and made room for social and other welfare expenditures. During the period between 1960 and 1985, the gross domestic product actually increased two-and-a-half-fold. From 1960 to 1973 the average annual growth in the gross domestic product was a huge 5 percent, and in the period $1974-85$ the average was 2.8 percent. It has been estimated that the major portion of the increase in the domestic product can be explained by an increase in productivity. As a result of the shortening of working hours, the number of completed work hours has actually decreased. Modern economic growth is based mainly on know-how and increasingly less on the quantitative growth in work input.

Population factors which have influenced production input include the increase in the supply of labor, characterized by the rather high labor participation rate of women, apparently the highest for the entire 20th century in Western Europe. This has been made possible, in part, by the increase in day-care services. The change in the family tax burden has also been seen to have contributed to the situation, when in 1975 spouses began to be assessed separately in conjunction with a new income and property tax system. The increase in productivity, again, is due not only to the increase per person in capital investment but also to qualitative factors pertaining to labor, which are affected by education and health care, for example.

\section{Population development and public finance in the future}

\section{Long-term commitments}

There is reason to believe that, in the future, demand factors resulting from population development will have an increasing impact on public finance. Within the social security sector, commitments have been made with very long-term effects and which will lead to future expenditures. These commitments will not be readily dissolved. The level reached in discretionary benefits also indicates the course of future expenditures.

Among long-term commitments, pension security is naturally the most significant. Social insurance, as well as subsistence security, have been perfected also in other respects, however. Reforms made in the 1980 s have improved national pensions, health insurance, unemployment security and security subsistence benefits. In Finland, the coverage of systems insuring a person's subsistence in case of a lack or severance of regular income is so encompassing that, in practice, we already al- 
most have a system of citizen's pay. It is true, however, that different groups receive this pay under different headings ard in different amounts (Figure 2).

Actual citizen's pay might mean, primarily, unifying the benefit levels of the various income-transfer systems.

In the area of social and health-care services, the development of day-care and health-care services are the most significant factors increasing expenditures. In social and health care, the Council of State ratifies personnel plans for five-year periods, and these are used to direct resources into different areas. The aim of this planning system is to guarantee an increase in the supply of services over a medium term, but the system's permanence insures decisions concerning the supply also over a long period.

Figure 2. The minimal security of a person living alone, by benefits, in 1987 and changes from the previous year. No earned income.

DHI MK/Month

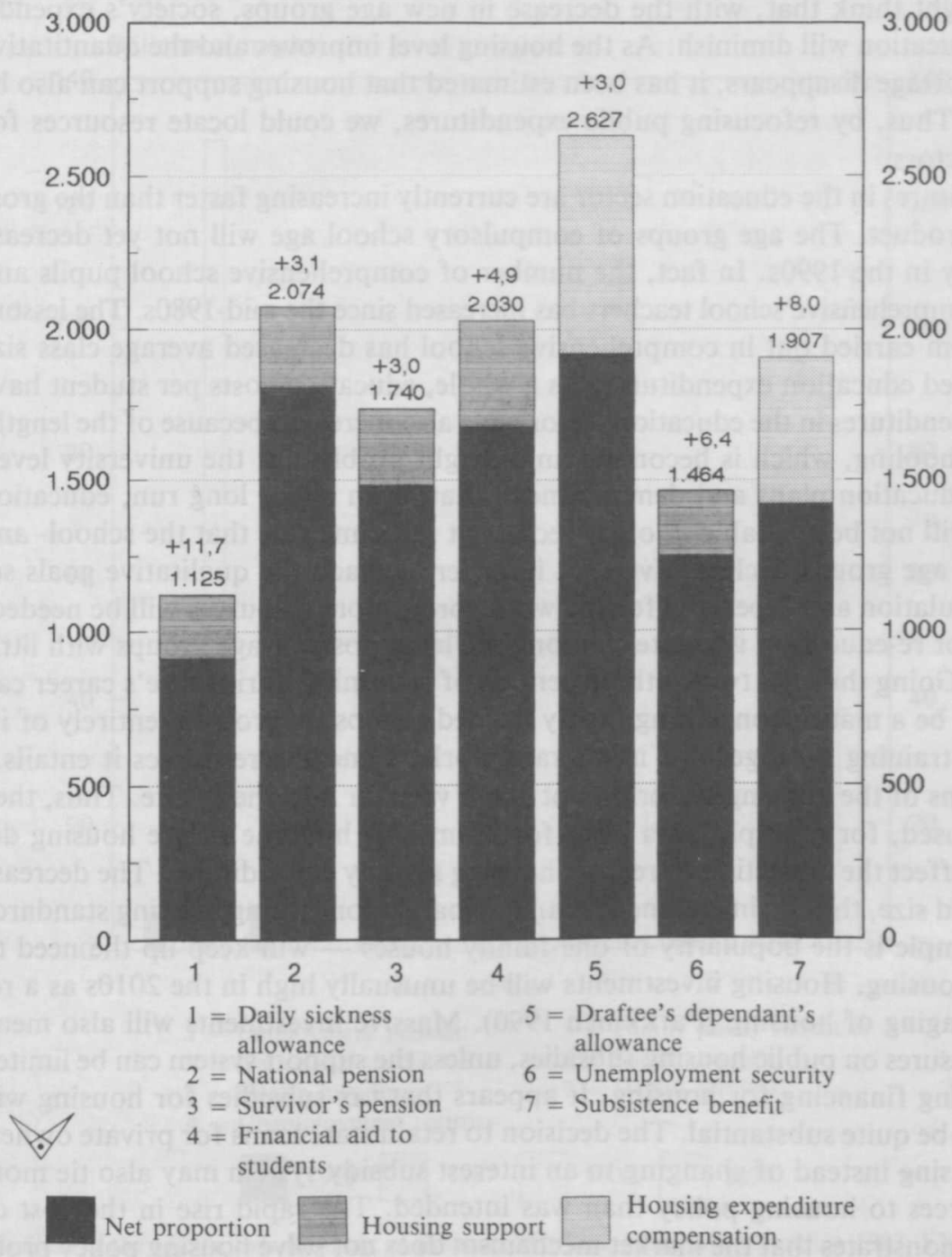

Source: Ministry of Finance, Planning Secretariat. 
So far, in estimating the expenditures caused by services, we have been able to assume that workers will be available at the same rate as new jobs are opened. It has been estimated that the number of jobs in social and health care will increase by 60,000 persons by the year 2000 . Under the circumstances, it no longer seems as clear as it has in the past that this plan can be carried out, for it is estimated that the entire labor supply will increase during the 90 s by a total of about 35,000 persons. There will be stiffening competition between the private and the public sector for workers already before the turn of the century, when the supply of labor will start to decline.

The demand for labor necessitated by social and health services will be considerable in the future. It has been estimated that the annual input of social and health services, including private services, is currently 400 million man-hours (Arajärvi and Parkkinen 1989). This is about 10 percent of the entire labor input of the national economy. In the year 2030, the labor input demand for these services has been calculated at 700 million man-hours or 25 percent of the estimated total input of 2,800 million man-hours at that time.

One might think that, with the decrease in new age groups, society's expenditures on education will diminish. As the housing level improves and the quantitative housing shortage disappears, it has been estimated that housing support can also be decreased. Thus, by refocusing public expenditures, we could locate resources for growing sectors.

Expenditures in the education sector are currently increasing faster than the gross domestic product. The age groups of compulsory school age will not yet decrease significantly in the 1990s. In fact, the number of comprehensive school pupils and full-time comprehensive school teachers has increased since the mid-1980s. The lessonframe system carried out in comprehensive school has decreased average class size and increased education expenditures. As a whole, education costs per student have grown. Expenditures in the education sector have also increased because of the lengthening of schooling, which is becoming an outright problem at the university level.

Adult education plans and demand mean that, even in the long run, education resources will not be available to other sectors at the same rate that the school- and college-age age groups decline. Even so, in order to reach the qualitative goals set for the population and especially for the work force, more resources will be needed. The need for re-education is greatest among the large postwar age groups with little schooling. Going through two or three periods of retraining during one's career can just as well be a matter concerning highly trained groups. A problem entirely of its own is the training arranged for immigrant workers and the resources it entails.

The plans of the housing sector do not reach very far into the future. Thus, they cannot be used, for example, as a basis for estimating how the future housing demand will affect the allocation of regular housing subsidy expenditures. The decrease in household size, the rise in real income and demands concerning housing standards - one example is the popularity of one-family houses - will keep up the need to construct housing. Housing investments will be unusually high in the $2010 \mathrm{~s}$ as a result of the aging of housing (Parkkinen 1990). Massive investments will also mean growth pressures on public housing subsidies, unless the support system can be limited by developing financing for housing. It appears that tax subsidies for housing will continue to be quite substantial. The decision to retain state loans for private ownership of housing instead of changing to an interest subsidy system may also tie more state resources to housing policy than was intended. The rapid rise in the cost of housing demonstrates that the market mechanism does not solve housing policy problems justly, in the social sense, at least not very quickly. If the situation continues 
to be just as difficult in the future, because of planning problems concerning land use and the alleged lack of true competition in the construction field, it cannot help but affect the housing subsidy systems also and, thus, total public expenditures.

\section{The future development of social expenditures and financing}

On the basis of current commitments and the official population forecast, social expenditures will, in reality, double by the turn of the century and triple by the year 2030 (Figure 3).

The growth in employment pensions is conspicuous. If, in the national economy, as much were to be paid out this year in pensions, in absolute figures, as in 2030, the current state budget alone would not be sufficient to cover them.

Figure 3. Social expenditures in 1970, 1987, 2000 and 2030 at 1989 prices.

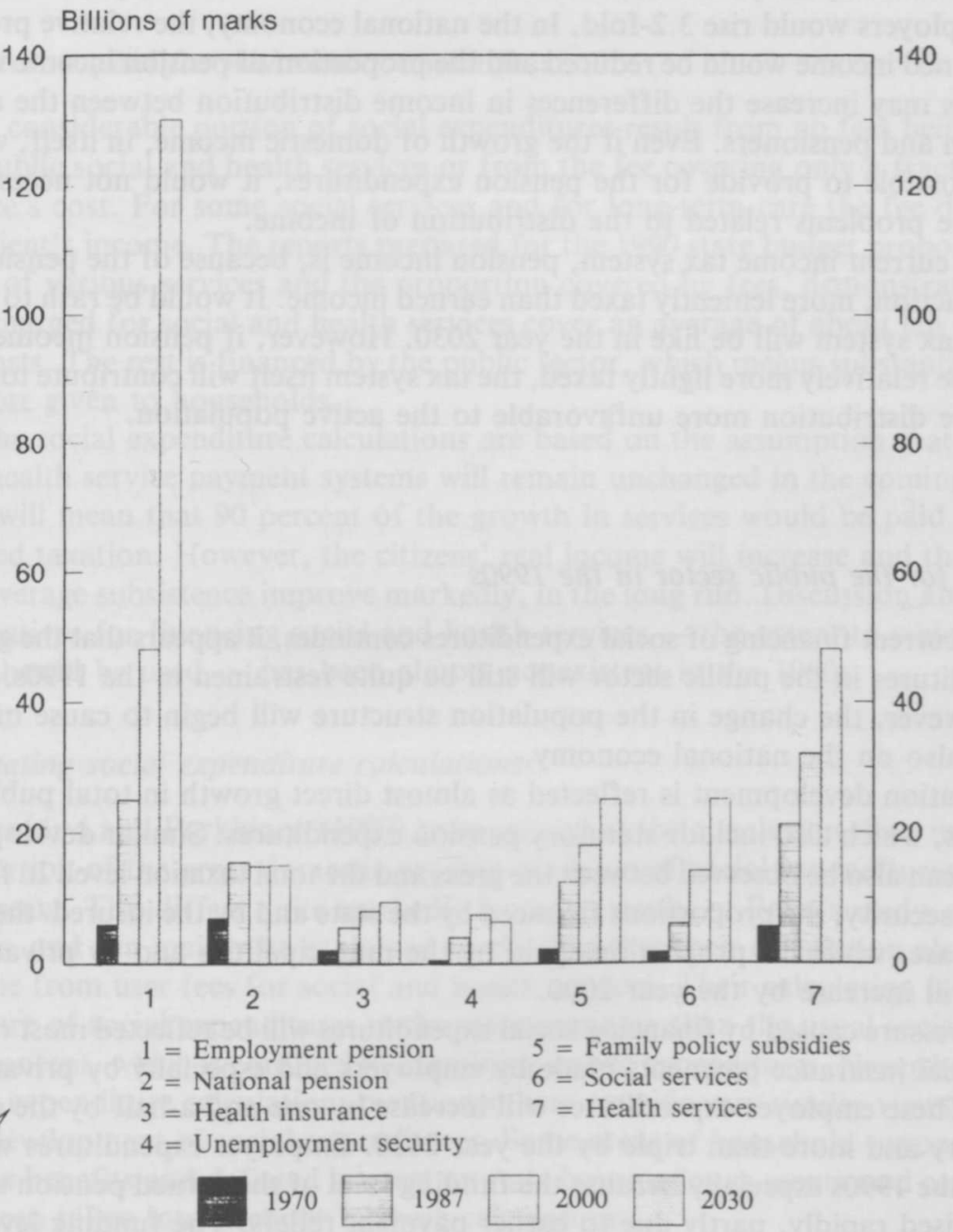

Sources for the calculation: Ministry of Finance: Working group Memorandum 1987: VM 12 (social expenditure classification and the years 1970 and 1987), Palm 1989 (growth in expenditures 1987-2030). 
The growth of the national economy must continue, if the public sector is to provide for its social expenditure commitments. Social expenditure calculations suggest how large growth must be, so that there will be enough of the cake, not only to finance public expenditures, but also for the needs of the active population and of production.

The latter demands mean, in practice, that

- the real income of the active population may rise

- employment can be guaranteed

- the employers will be able to provide for rising social security payments.

According to Palm's (1988) calculations, the gross domestic product should grow an average of 1.7 percent annually up to the year 2030, so that these goals could be reached. During this century, the annual growth percentage should be an average of 2.4 percent and, after that, an average of 1.3 percent.

Even if the economic growth described above were actually to occur in the future, there will still be tangible and inevitably problematic effects concerning distribution related to this development. For example, if total salaries were actually to increase 1.7 -fold by the year 2030 , the total amount of social security payments paid by the employers would rise 3.2 -fold. In the national economy, the relative proportion of earned income would be reduced and the proportion of pension income would grow. This may increase the differences in income distribution between the active population and pensioners. Even if the growth of domestic income, in itself, would make it possible to provide for the pension expenditures, it would not necessarily remove the problems related to the distribution of income.

In our current income tax system, pension income is, because of the pension income deduction, more leniently taxed than earned income. It would be rash to guess what the tax system will be like in the year 2030. However, if pension income continues to be relatively more lightly taxed, the tax system itself will contribute to making income distribution more unfavorable to the active population.

\section{A respite for the public sector in the 1990s}

If the current financing of social expenditures continues, it appears that the growth of expenditures in the public sector will still be quite restrained in the 1990s. After 2030 , however, the change in the population structure will begin to cause marked pressure also on the national economy.

Population development is reflected as almost direct growth in total public expenditures, which also include statutory pension expenditures. Similar developmental trends can also be observed between the gross and the total taxation level. In financing social security, the proportions financed by the state and by the insured/the users will decrease, while the proportions paid by the municipalities and by private employers will increase by the year 2000 .

The pressure caused by financing social expenditures will be reflected most rapidly in the social insurance payments made by employers and especially by private employers. These employer expenditures will increase by one-and-a-half by the end of the century and more than triple by the year 2030 . Employer expenditures will increase in the 1990s especially because the funding level of the earned pension system will be raised rapidly, partly due to earlier payment reliefs. The funding level will be raised again in the 2000 s, so that the reserves will start being lowered around the year 2015 . 
Table 2. The estimated development of social expenditures, public finance and the taxation level up to the year 2030 .

\begin{tabular}{llcl} 
& \multicolumn{3}{c}{ Proportion of the GDP, percent } \\
Social expenditures & 1987 & 2000 & 2030 \\
Public sector expenditures & 22.8 & 27.0 & 33.3 \\
Total public expenditures & 41.6 & 42.0 & 46.0 \\
Gross taxation level & 45.5 & 47.6 & 56.0 \\
Total taxation level & 37.0 & 38.3 & 42.0 \\
& 41.0 & 45.0 & 51.0
\end{tabular}

Source: Palm 1989.

In the year 2030, social expenditures would equal exactly one-third of the gross domestic product (Table 2). It is has been assumed that public expenditures other than social expenditures will grow, in the long term, so that their share of the gross domestic product will remain on the current level.

\section{Services - paid for with taxes or with fees}

A considerable portion of social expenditures result from no fees being charged for public social and health services or from the fee covering only a fraction of the service's cost. For some social services and for long-term care the fee depends on the client's income. The reports prepared for the 1990 state budget proposal, on the costs of various services and the proportion covered by fees, demonstrate that the fees charged for social and health services cover an average of about ten percent of the costs. The rest is financed by the public sector, which means substantial indirect support given to households.

The social expenditure calculations are based on the assumption that the social and health service payment systems will remain unchanged in the coming decades. This will mean that 90 percent of the growth in services would be paid for by increased taxation. However, the citizens' real income will increase and the pensioners' average subsistence improve markedly, in the long run. Discussion about future alternatives for financing social and health services - the extent to which taxes or fees should be used - has been almost nonexistent in the $1980 \mathrm{~s}$.

\section{Evaluating social expenditure calculations}

Arajärvi and Parkkinen (1989) have arrived at the conclusion that, in 2030, the proportion of the gross domestic product made up of social expenditures would be 37 percent. This differs quite markedly from the results of Palm's study, mentioned earlier, and can mainly be explained by the fact that their calculation also includes income from user fees for social and health services. Their calculation is a broader measure of social expenditures in the state economy than the usual social expenditure concept, which is confined to examining public expenditures. Nevertheless, both social expenditure calculations mentioned here provide very similar views of the future development of social expenditures. Some areas of household support, such as the tax benefits and deflated interest on state housing loans mentioned earlier, have not been taken into account in these calculations.

According to the social expenditure reports examined above, public finance will not be expanding very substantially in relation to the domestic product. No insur- 
mountable problems are expected in balancing the public sector. This view is based (Arajärvi and Parkkinen 1989) on the fact that pensions, which have a crucial effect on the growth of social expenditures, and which will be increasingly larger in the future, on the average, will partially revert to the public sector in taxes. The rise in the level of taxation may, in itself, cause problems. These problems could be alleviated by raising the proportion covered by user fees, as presented in the report. However, the unavoidable increase in the tax burden would cause effectiveness losses, which have not been assessed in either calculation and which, according to some new international studies, are quite notable, for example, in Sweden. The difference between the employer's wage costs and the wage earner's actual take-home pay will continue to grow markedly. The report assumes that the growth of other public expenditures will also be quite moderate.

Both social expenditure calculations are quite optimistic about the future. According to these calculations, the development of the population structure does not seem to be leading to any serious problems in public finance.

In principle, we have both the time and the possibility to prevent the problem from becoming too serious. But will society still have enough time to adjust? The labor shortage prevailing in the current boom period indicates that the development of the population structure is not only a problem concerning social expenditure demands. The decreasing labor supply may cause uncertainty already in the coming decade, regarding the very long-term goals for the growth of the gross domestic product. Can productivity be increased in order to induce growth? Improving the productivity of public services is at least as important an issue as developing the productivity of the entire economy. Large investments are required to increase productivity, but in financing them we come up against the decline in the savings rate. This problem in financing investments will also have to be considered in the total assessment of the national economy.

The coming change in the population structure will be historically unique. Not all of its consequences have yet been clarified. Some indication of the future society can be seen in municipalities where the population's age structure already corresponds to the structure predicted for the whole country in 2030 . The problems these municipalities are facing in public finance cannot tell us, however, what will happen to future public expenditures in the state economy, because these municipalities receive marked outside state subsidies. The national economy cannot be subsidized from the outside like this.

On February 22, 1988, the Council of Ministers of the European Community, on France's initiative, expressed its deep concern about future population development in Europe: ». . .the alarming population development occurring in Europe means that Europe cannot retain its political, economic and cultural position in the world without renewing its population dynamics. $\aleph^{2}$

\section{Influencing population development}

\section{Economic theories concerning population development}

Can public policy measures be used, then, to influence population development? Economic theories regarding population development are attempting to analyze the

${ }^{2}$ Communication from the Commission on family policies, COM (89) 363 finel, Brussels, August 8, 1989, Commission of the EC. 
effect of economic factors on this phenomenon. ${ }^{3}$ Most population policy measures specifically try to influence the family's finances, so that an economic analysis may provide us with more insight into this question, which in itself is a very difficult one.

For the national economy, the key problems in the current population development are the following:

- the aging of the population structure is increasing the public sector

- the decline in the birthrate is decreasing the labor supply absolutely necessary for economic growth

- the development of the population structure does not favor saving, which is required for funding investments necessary for the growth of the national economy. According to forecasts, the population of Finland will continue to grow up to the turn of the century, but after that it will begin to decline. One internal factor in the population structure affecting the situation is that the fertile age groups are increasingly smaller. In addition, fertility is declining, because people are having children at an ever later age, and the average number of children per family has decreased.

The rejuvenation of the population's age structure requires an increase in fertility. If this occurs, it means, at the least, a rise in the demand and need for child-care services, education services and family housing. The pressure on increasing public consumption is great, because the income of young families is smaller and their buying power less than in older families. A permanent rise in fertility permanently increases the demand for these commodities. In a society with an aging population structure, it is the demand and need for welfare for the aged and health services that increase. Such a society would probably have more affluent people with buying power.

The relation between population development and economic growth is one of the focuses of interest in population economics. By placing population factors in economic models, Simon (1986) has reached findings according to which population growth has a positive influence on economic growth. Simon's analyses are based on the idea that population growth creates a greater labor supply and a broader base for talent reserves, which increase the probability of reforms. Inventions have been key factors in the growth of productivity and the national income. Inventions arise by combining new ideas with old ones, and in principle there is no limit to their growth.

In the 1990s, smaller age groups will be in their prime renewal stage. If the Easterlin-hypothesis ${ }^{4}$ holds true, fertility would then be greater than indicated by the official population forecasts. These forecasts have not taken theories like this into account. The most recent empirical research, however, questions the Easterlin-theory's ability to explain the issue. The theory is perhaps too rough in character to provide regular population forecasts with essential additional information or to act as a basis for population policy measures (Wright 1989). Macroeconomic approaches have not appeared, up to now, to have come to the aid of population policy with any other very practical results, either.

\section{A microeconomic model for fertility in the modern society}

The goal of current family policy measures is to compensate at least part of the

${ }^{3}$ It must be noted, however, that after Malthus economics has dedicated very little attention to population development. Usually, the population has been included in economic models as a given outside factor.

According to the Easterlin-hypothesis, the level of fertility affects the size of the fertile age groups. The fertility of the large age groups is low, because during their lifespan they have to fight a tighter »battlew, in making their career, for example, than the smaller age groups. Life will be easier for the latter, which would later be visible also in a higher fertility (Ohlsson 1988). 
additional economic burden of having a child. It is believed that having or not having a child is, at least partially, an economic question.

Even though one goal of social policy has been to care for the position of children and thereby fertility, population development is still considered a given factor. This is even truer in economic policy planning.

In economics, several branches of research focusing on specific issues have developed and are continuing to develop. In fertility economics theory the child is examined as a "commodity», for which there is a certain demand. Decisions concerning demand are made independently by each family. The child competes with other commodities. The child can also be examined as a focus of investment, with alternatives to be found to making investments in a child (for example, Eriksson 1989). Another aspect is examining the time spent on child care as part of the family's optimal use of time.

In a modern society, the state directs the economy through numerous direct and indirect measures. Outright directives, direct benefits, indirect subsidies and taxation affect the economic decisions made by households and enterprises. Because having children is at least partially an economic decision, this direction made by the state also affects the decision. What is essential is that the effect does not arise solely by means of so called family policy. Without too much exaggeration, one could say that almost all the features of the welfare state must be taken into account in fertility economics.

Fertility often remains low in the welfare state because (Demeny 1989):

- The child the family is considering having, and especially an additional child, will cause the parents decreasing additional benefit and increasing costs. In a traditional society, the child participated in work from an early age and, at least in the long run, affected the family's income. The modern society demands a long and broad investment in psychological capital, before it allows entry into the labor market. Even though the government bears a large share of the costs of education, the long schooling period adds to the costs of providing for the child.

- An increasing alternative cost is associated with the child. In the western world, also in Finland, women participate extensively in the labor force. The economic compensation for work exceeds the benefit obtained in caring for one's own child. Even if caring and bringing up one's child would be satisfying and a challenging job, even monotonous line work can assure more secure economic prospects. In addition, the workplace often provides a more stimulating social environment, a factor valued today.

- By creating pension systems, modern society has taken over almost the entire responsibility for guaranteeing old-age subsistence. The income-transfer society does not leave the arrangement of subsistence during old age to the individuals themselves, instead it carries out very extensive income transfers between active age and old age (funded pensions), on the one hand, and between the active-aged population and the pensioned population (unfunded pensions and other income transfers and services), on the other. The need to have a large family in order to provide for one's old age has become history. Old-age security has not been able to develop, nor is it likely that it will in the future, without affecting fertility. The pension systems have created the illusion that young people are no longer needed to insure one's old age.

The significance of the society's level of development for fertility is shown concisely in Figure 4. In an agricultural society, increasing the number of children has favorable effects, from the parents' point of view, on both production and subsistence, as well as on old-age security. Child care is no special added burden. In an industrial society, the immediate favorable impact of children on production and 
Figure 4. The impact of having more children on the parent's (the previous generation's) situation in an agricultural and an industrial society.

\begin{tabular}{|l|l|l|}
\hline & Agricultural society & Industrial society \\
\hline $\begin{array}{l}\text { Impact on } \\
\text { work input }\end{array}$ & $\begin{array}{l}\text { Helps, children participate } \\
\text { in household production }\end{array}$ & $\begin{array}{l}\text { No impact. Parents at work, } \\
\text { children at home }\end{array}$ \\
\hline $\begin{array}{l}\text { Impact on } \\
\text { child care }\end{array}$ & $\begin{array}{l}\text { Grandparents or older } \\
\text { children care for children }\end{array}$ & $\begin{array}{l}\text { More difficult, childcare costs } \\
\text { increase }\end{array}$ \\
\hline $\begin{array}{l}\text { Impact on } \\
\text { social } \\
\text { security }\end{array}$ & $\begin{array}{l}\text { Helps, the more children, } \\
\text { the more certain security is }\end{array}$ & $\begin{array}{l}\text { The effect is cut off at the microlevel } \\
\text { because of the social security systems; } \\
\text { illusion that pension security is not } \\
\text { dependent on the population structure }\end{array}$ \\
\hline
\end{tabular}

old-age security disappear. Child care becomes an additional economic burden or, at least, having children faces strong competition from other choices.

The development of the population structure also affects political institutions. In a democracy of adults, based on the principle of "one man, one vote», the aging of the population structure transfers power to increasingly more elderly population groups. There has been discussion of the concentration of political power to pensioners, but, in reality, interest in benefits related to being pensioned arises much earlier, perhaps already before one's 50th birthday. Current population development may lead to a future situation, where more weight is given to the needs of the more elderly population groups. In allocating resources, measures aimed at improving the welfare of the more elderly groups and, on the other hand, the aim of maintaining sufficient fertility may be contradictory, unless the cake being divided up is big enough.

\section{Population policy measures}

Regarding the entire economy, the whole structural change taking place is what is problematic in population development. The decline in fertility is one structural factor, a key one in the long term. Thus, population policy measures must be evaluated in relation to this whole. On the macrolevel, one can assume that a population structure could be found, which would be ideal regarding supply and demand. Finland's population structure today and in the decade to come is perhaps closer than ever to being ideal.

It is not exaggerating too much to claim that almost all public measures affect the welfare of the population and population development. Despite the $»$ wide» array of measures available, we do not know very much about the exact impact of these measures. This makes it more difficult to choose measures in formulating an effective population policy. It is essential to remember, however, that population policy is not only social policy, but most fundamentally also economic policy.

In the regular planning of economic policy, population development is considered an exogenic factor, determined outside the economic models. This is probably primarily due to the fact that, in formulating economic policy and its models, the emphasis is on predicting and directing cyclical development. Nevertheless, each main economic policy goal has a demographic aspect of its own, in the long run. On the 
other hand, the goals of economic policy, in themselves, are not contradictory to population policy goals.

Maintaining economic growth is population policy, because the sufficiency of funding for social expenditures depends on it, and also because population growth and structure affect the domestic product. The significance of employment for the welfare of the population is clear. Balancing income distribution is not only an economic policy goal but also a fundamental social goal affecting the welfare of the population. There are population policy aspects to the stable development of prices: one example is the rapid rise which has occurred in the cost of self-owned housing in the last few years. Its impact on the possibilities for forming a family and having children can only be surmised at this stage.

As a basis for evaluating family policy income transfers and services, the following four assumptions can be condensed from fertility microtheory:

- The less society compensates marginal costs arising from children, the weaker fertility will be.

- The higher the salary women will lose and the smaller their chances to return to work and to further their career, the lower fertility will be.

- The more the culture demands from education, clothing, nutrition, housing and leisure time, the weaker fertility will be.

- The more funding is needed for pension insurance, either funding through taxation or as a funding system, the weaker fertility will be.

If these assumptions are true, fertility can be improved by increasing child benefits, parental leave per diem allowances, support for education and studying, and housing policy support to families with children. What is essential is the scope the measures will take. A fundamental problem is, first, that our knowledge about the magnitude of the effects is almost negligible. Very little quantitative research on effects has been done. Another problem is how these measures will be financed and who will do the financing, because these decisions will affect both income distribution and, through the tax burden, efficacy losses in the entire national economy.

The effects of developing health care are not unequivocal. It is clear that health services improve the quality of the population by decreasing morbidity. On the other hand, health care competes with other sectors for workers and investments. In demand, health care may compete, to some extent, with other commodities affecting welfare.

Education and re-education improve the quality of the population. However, it is somewhat unclear how problems relating to population structure can be mended by improving the quality of the population. There are perhaps two aspects where the effects of education favorable to the national economy can be observed: through education, the correspondence between the supply of labor and demand can be improved, and (re-)education can be used to decrease premature retirement. It has been suggested that the talent and ability reserves in the population limit the extent to which education can compensate the decline in the quantitative supply of labor. On the other hand, it has been estimated that especially the increase in the demands on the education and work tasks of women will weaken fertility considerably.

Pension security is financed partly by the individual's own active age employment, partly by the taxes paid by younger generations or by employer payments. The pension systems may create the illusion that old-age security is not dependent on one's own decisions about having children. Thus, apparently, the pension systems themselves have a weakening effect on fertility.

Although Finland's housing conditions, on the average, are beginning to be satisfactory, the current supply of housing is not sufficient in many areas, and the prices 
are high. The problems faced especially by new households in finding housing and the high housing costs in the early part of the lifespan increase the economic burden of having children. As long as housing support is capitalized in the price of housing, the situation of people purchasing their first home becomes more difficult, because the support is not focused on the time when housing is being purchased, instead it is distributed over a longer period. The significance of housing policy as a means of population policy will probably continue to be a current issue in Finland for a long time.

In Finland, we are finding ourselves, for perhaps the first time in history, in a situation where immigration might be needed to solve the economic problems caused by the population structure. This will happen, if the decline in fertility continues throughout the 1990 s as predicted and the labor demand forecasts come true. If fertility development does not change, it is estimated that, in the coming decades, Finland will need an annual net immigration of as many as 25,000 persons, so that the population would not begin the decline predicted for the beginning of the next century (Söderling 1989). This number corresponds to about 40 percent of the annual number of births in the last few years. The country would gain permanent new inhabitants equal in number to about two rather large rural municipalities, with gross immigration even more extensive as a result of return migration among the arrivals.

Continuing to lower the voting age could be one way to balance political power between young and old age groups, as the population structure ages. Is there some way to estimate what the political consequences will be, however? Would a better alternative be that parents would have an additional vote for each child who is a minor?

\section{The effects on fertility of decisions already made}

Is it possible to influence fertility? If the answer is affirmative, how substantial must the measures be before there are any significant results? A rather common opinion in population research appears to be that intensifying family policy only temporarily affects fertility. This opinion is based on Hungary's and France's experiences, which are often referred to in this connection.

In Finland, fertility declined sharply after the 1950 s and was at its lowest in the early 1970s. In 1973, the total fertility rate was 1.5 , while it had still been 2.14 in 1968. Since 1968, fertility in Finland has not reached the level necessary for renewal (Figure 5).

In the 1960 s, the significance of family support in relation to the income available to households diminished. This may be one reason why fertility declined. It is probably not very easy to estimate its effect, because many other phenomena occurred at the end of the 1960s and the early 1970s, which decreased rather than increased fertility, such as rural depopulation and emigration to Sweden.

Family policy support was increased in the 1974 income distribution agreement. The Child Day-Care Act had already been enacted earlier. In fact, starting then, family support has grown, both relatively and absolutely, as a result of decisions which have been repeated quite often. The timing of the most important decisions is presented in Figure 5.

In addition to the increase in family policy benefits, changing over to the separate taxation of spouses in 1975, which decreased the tax burden on families, may have increased fertility, to some extent, by improving the expectations families had concerning their income. At the same time as being employed became more advantageous to women in regard to taxation, the prospects of finding day care also started 
Figure 5. Live births in Finland in 1960-2030.

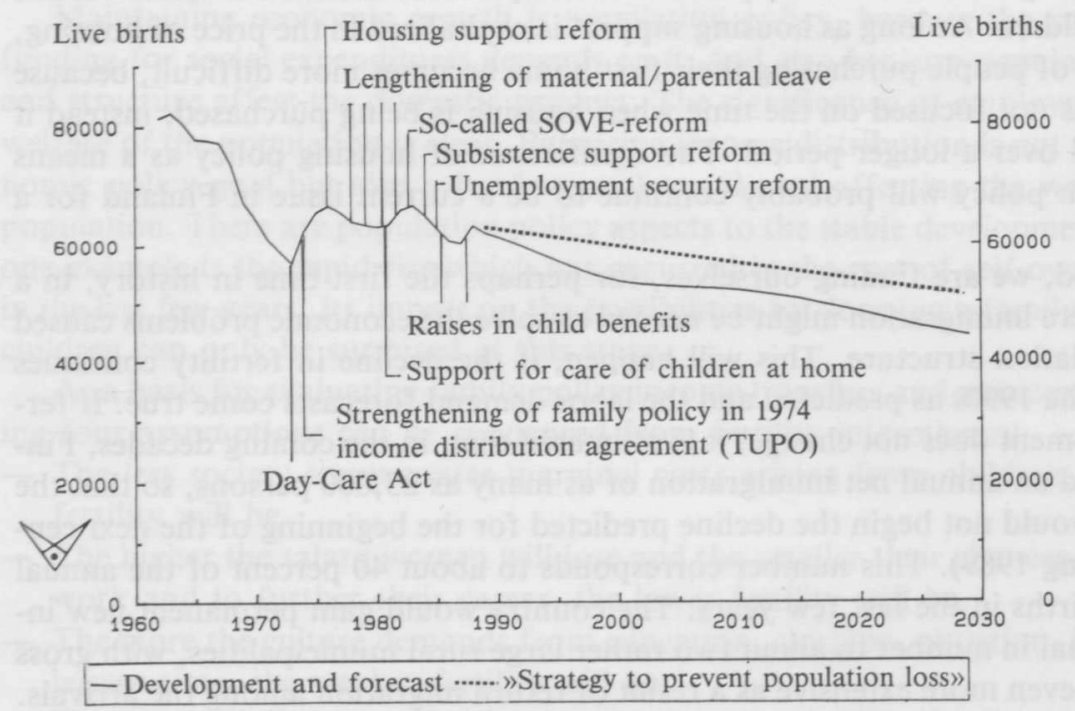

(SOVE = increase in sick leave and parental leave per diem allowances along with their taxation)

Sources: Population statistics and the Social Insurance Institution 1989 forecast.

to improve. On the other hand, the increase in the participation of women in the work force may also have had the opposite effect on fertility.

Family support, which improved in the 1970 s, has remained about the same, in proportion to the gross domestic product, throughout the 1980 s (Table 3 ). Its internal structure - including raises in parental leave per diem allowances and the increase in daycare places - has perhaps become more »effective», however, regarding the decision to have children.

In examining how the quantity of family support and the timing of family policy measures have developed, the question arises about what aspect of family policy really has an effect. The actual level of family support has a great significance, of course. The kibbutzim of Israel have been mentioned as an extreme example of this, because there the community takes the entire responsibility of caring for the children. There the total fertility rate is 0.5 percentage points higher than elsewhere in Israel.

In estimating the actual level of family support in historical time series, one should be aware of the situation entitling one to benefits. The actual economic significance of child benefits today is smaller than in the 1950s. This is true both numerically and, also, because now that we live more purely in an exchange economy, the additional advantage obtained from child benefits is smaller than when we were still living mainly in a natural economy. This was still the case in the 1950s.

On the other hand, the impressiveness and regularity of family policy measures, their recurrence, may be significant, as may be the visibility of the support to families. In the latter respect, income transfers and services may have a greater effect than tax subsidies.

Family support is not only limited to the measures described in Table 3. For example, there are family policy components connected to housing benefits, such as 
grading according to the number of children. It has been estimated that, if these were taken into consideration, the amount of family support would increase by as much as one-half, compared to the total presented in the table.

In Finland, the total fertility rate has remained at about an average of 1.7 since the mid-1970s. It is extremely difficult to estimate the effects of family policy on fertility during this more than ten-year period. One rough estimate is obtained in the following manner: while the total fertility rate in other Western European countries comparable to Finland declined during this period by about $0.2-0.3$ percentage points, one could assume that the development of Finland's family policy and other social policy has had this large an effect, assuming that the level of benefits has not changed in the other countries. Finland, in the 1980 s, has been almost the only Western European country, where social expenditures have been increased rather than reduced. It is clear, in any case, that the current total fertility is not enough to renew the population in the long run. The decrease in the size of the age groups, again, will result in a decline in the number of births, as shown in Figure 5. An interesting question is how much more family support would be needed for a successful »strategy of prevention against population loss» (Sneck et al. 1989).

\section{The impact of population and economic development on future social expenditures}

According to Palm's (1988) calculations, social expenditures in the national economy would thus, on the basis of »reasonable initial assumptions», consist of onethird of the gross domestic product in the year 2030. Changes in the initial assumptions, some of which concern population change factors, will not affect the future proportion of social expenditures in the gross domestic product very much (Table 4).

Table 3. Family policy support in 1960-1989, in millions of marks.

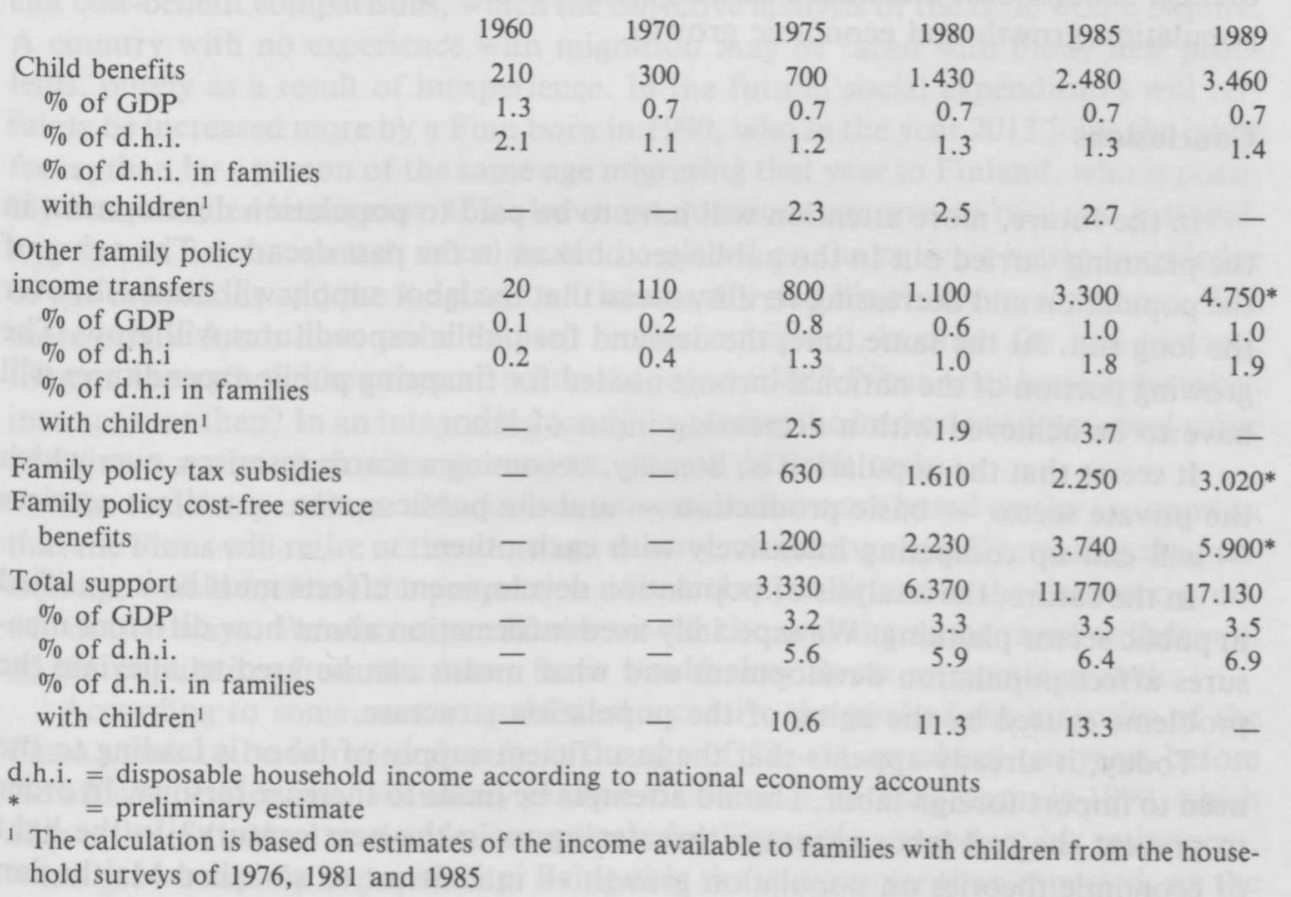


Table 4. The impact of various alternatives for development on the proportion of social expenditures in the GDP in the year 2030.

Social expenditures

Percent of GDP

Basic alternative

Lifespan does not increase

Faster growth of the GDP

Pension age rises by one year

Fertility increases

Fertility decreases

Pension age decreases by one year

Lifespan increases

Slow growth of the GDP

33.3
33.3
32.5
33.0
33.5
33.8
33.8
34.1
35.6

The differences between the various alternatives for the development of social expenditures seem slight, when measured as a proportion of the gross domestic product. In absolute figures, these are rather large sums, however. In the basic alternative presented by Arajärvi and Parkkinen (1989), the gross domestic product would be about 800 billion marks, at the current rate, in 2030 . This would mean, for example, that if the growth of the lifespan stops where it is now, according to Palm's calculations, this would lead to 14.4 billion marks less in social expenditures than in the basic alternative in the year 2030. On the other hand, the increase of fertility to the level necessary for renewal by the year 2010 would only increase social expenditures by 1.6 billion marks, but a decrease in fertility would increase them by 4 billion marks. These calculations concerning different alternatives have not estimated what measures and what kind of an increase in family policy expenditures would be needed to increase fertility. At least on the basis of these assumptions, an increase in fertility would be a more favorable alternative for the national economy than its decrease. The result of the formal calculation would appear to support Simon's theoretical conclusions, mentioned earlier, concerning the positive correlation between population growth and economic growth.

\section{Conclusions}

In the future, more attention will have to be paid to population development in the planning carried out in the public sector than in the past decades. The aging of the population and decreasing fertility mean that the labor supply will diminish, over the long run. At the same time, the demand for public expenditures will grow. The growing portion of the national income needed for financing public expenditures will have to be achieved with a decreasing input of labor.

It seems that the population is, literally, becoming a scarce resource, over which the private sector - basic production - and the public sector - welfare services - will end up competing intensively with each other.

In the future, the analysis of population development effects must be intensified in public sector planning. We especially need information about how different measures affect population development and what means can be used to alleviate the problems caused by the aging of the population structure.

Today, it already appears that the insufficient supply of labor is leading to the need to import foreign labor. Should attempts be made to increase fertility, in order to prevent the real labor shortage threatening us in the next century? In the light of economic theories on population growth - in contrast to so-called Malthusian 
views - this seems fully justified. But is increasing fertility any longer a self-evident and an only alternative to reaching a more balanced population development. Increasing fertility requires augmenting public family policy expenditures. But how much? The settling of fertility in the 1980 s somewhat higher, on the average, than the level at the end of the 1970 s may be due, in part, to the joint effect of various consecutive family policy measures. If the effect on the total fertility rate would have been 0.3 percentage points, for example, would even doubly intensified solutions have led to or lead in the future to renewal of the population. It is very possible - considering that international development is very similar - that it is not possible to raise family policy support so high, that fertility would reach the level of population renewal.

Another problem in family policy is how much time we have in the current situation to aim for fertility leading to population renewal, without having so-called transition period problems. For example, the »instantaneous» rise of fertility to the level required for population renewal would also lead to an undesirable »baby boom» in the 2010s-2020s. The large age groups will be retired then and will need increasing services. Then antiquated housing would also necessitate larger than normal investments (Parkkinen 1990).

One problem is choosing the right measures. Direct income transfers may be more impressive than indirect benefits, for example, tax deductions for families with children. No reliable empirical data can be found to support this assumption, however. If family policy is to be intensified, more expenditures will clearly be needed than the social expenditure calculations indicate. In order that family policy does not cause additional pressure on the public economy, public expenditures should be allocated and financed differently than now. But will the politicians be able to reach an agreement?

In an overpopulated world, one can demand, of course, that in addition to family policy, and as an alternative, an increase in immigration should be allowed or even encouraged. In weighing the alternatives, we may find ourselves making really difficult cost-benefit comparisons, which the objective analysis of the issue would require. A country with no experience with migration may be faced with many new problems, purely as a result of inexperience. In the future, social expenditures will certainly be increased more by a Finn born in 1990, who in the year 2013 joins the labor force, than by a person of the same age migrating that year to Finland, who is possibly even a skilled immigrant. If we leave out questions concerning race and nationality, we can ask how much value should be placed on the native's better knowledge of the conditions and the language of the country and his ability to cope here. Will more public funds have to be focused on the immigrant, in order for him to cope, than on the native, when they arrive on the job market? What costs have to be taken into account then? In an integrating world, assessing the intrinsic and practical value of being a native, beforehand, may be quite a difficult task.

The social expenditure calculations presented above are based on the assumption that the Finns will retire at the same age as now, on the average. Decreasing the pension age would increase the proportion of social expenditures in the domestic product in two ways. Pension expenditures would rise and the more rapid withdrawal of the population from the labor force would slow down economic growth.

According to some surveys published recently, the goal of the majority of the Finns seems to be to retire already at the age of $52-54$, or about ten years before the official pension age. Voluntary pension insurance is the only means in 1990, which allows the individual to decide, completely for himself, to speed up his retirement. It has grown rapidly in popularity. Being able to retire sooner than expected, on the 
average, has definitely been influenced more, in the current situation, however, by the early retirement pension systems, whose popularity has exceeded preliminary estimates made when these reforms were being formulated. More rapid retirement builds up new pressure on the employed - this new fashion may be contagious.

Even if the surveys reveal verbal attitudes more than real attitudes, there is no reason to underestimate the results. Is a three-phase lifespan - childhood and basic schooling, participation in the labor force, enjoying retirement - too formal and stressing? Why do people want to stop working? Education has been emphasized as a means of raising the quality of the population, so that it will be better able to meet the demands of changing technology in production and the aims for productivity. It seems, however, that different ways of participating in the work force should also be developed, so that people would accumulate the number of working years, which were the aim when the current decisions about pension age were made. What one does at work should be made meaningful and seeking to retire less attractive.

Many so-called sector planning systems in the public domain are based on future population development. Forecasts form the basis for the social expenditure calculations of the Ministry of Social Affairs and Health and in the national plans concerning services. The quantitative planning of the education sector utilizes population forecasts. Estimates concerning the development of households and predictions concerning housing needs are based on population forecasts.

On the national level, population development is included in planning as a given factor. Goal-directedness can be seen mainly in the population plans of the Ministry of the Interior's regional planning department, where these plans help direct regional development and coordinate measures according to regional policy. These plans do not take a stand on the level of fertility or on population renewal, instead, the total population figure included in the plans corresponds to the official forecasts. In planning economic policy, population development is even more purely an exogenic factor, a factor determined outside the planning models, than in planning the functioning of the public sector.

Finland has no officially stated population policy aims. Regardless of whether such aims will be set in the future, it seems necessary to intensify the treatment of the population issue in public sector planning. To begin with, we will need more information about the effects of population development in regard to the public economy and the national economy. Above all, however, we will need information about the effectiveness of population policy measures. If we take these steps, we will be better prepared than now to handle the population question in making political decisions.

The frame of reference presented in this article could be one starting point for improving readiness on the information level. This would essentially entail the development of a theoretical and methodological approach, including the endogenization or incorporation of population factors into economic models. Research should be applied research, however, and concentrate on the structural problems arising from population development, in view of the current situation. This research could be modeled as a long-term program of investigation, and it might be suitable as the basis for long-term projections made at the Government Institute for Economic Research founded in October 1990. 


\section{References}

Arajärvi, Esa; Parkkinen, Pekka (1989). Hoiva-Suomi 2030: sosiaalimenot vuosina 1960-2030 (Social services and Finland in 2030: social expenditures in 1960-2030). Helsinki: Taloudellinen suunnittelukeskus.

Commission of the EC (1989). Communication from the Commission on Family Policies COM (89) 363 finel, Brussels 8.8.1989.

Demeny, Paul (1986). Population and the invisible hand. Demography 23 (4): 473-487.

Eriksson, Tor (1989). Lasten kysyntä, naiset ja työ (Demand for children, women and work). TTT Katsaus 17 (1): $78-85$.

Hjerppe, Reino (1986) Tulonsiirtojärjestelmän kehityksestä ja arvioinnista (On the development and estimation of income transfer system). In: Taulukoinnista tietoyhteiskuntaan, edited by Heidi Mikkola, Juhlakirja Olavi E. Niitamolle. Helsinki: Tilastokeskus.

The Social Insurance Institution (1989). Väestöennuste vuoteen 2050 (Population projection until the year 2050). Helsinki: Kansaneläkelaitos, laskenta- ja tilasto-osasto, matemaattinen toimisto.

Ohlsson, Rolf (1988). Ekonomiska aspekter på generationsstorleken (Economic aspects of the size of a generation). Ekonomisk debatt 16 (7): 550-558.

Palm, Heikki (1988). Sosiaalimenojen kehitykseen vaikuttavat tekijät vuosina 1960-2030 (Factors influencing the development of social expenditure in 1960-2030). Julkaisuja 3: 1988. Helsinki: Sosiaalija terveysministeriö, Suunnitteluosasto.

Palm, Heikki (1989). Sosiaaliturva ja julkinen sektori: kasvun syyt ja kehitysnäkymät (Will the public sector continue to grow). Sosiaalivakuutus 27 (3): 98-104.

Parkkinen, Pekka (1990). Asuntovarallisuus vuosina 1900-2030 (Residential wealth from 1900 to 2030). Helsinki: Taloudellinen suunnittelukeskus.

Simon, Julian L (1986). Theory of Population and Economic Growth. Oxford: Basil and Blackwell.

Sneck, Timo; Mäntylä, Kaj; Tuunela, Iiris; Himanen, Veli (1989). Suomi 2030: Suomen alueellinen kehitys vuoteen 2030 kolmena skenaariona (Finland in 2030: Finland's regional development until the year 2030 in three scenarios). Helsinki: Seutusuunnittelun keskusliitto and Neste.

Söderling, Ismo (1989). Mistä Suomi saa lisää väkeä? (From where will Finland get more people?). Helsingin Sanomat 17.12.1989.

TASKU (1986). Harmaantuva Suomi in 2030? (Greying Finland in 2030?). Helsinki: Taloudellinen suunnittelukeskus.

TMAE (1990). Verojärjestelmän kautta annettava tuki, liite nro 3. Valtion vuoden 1990 tulo- ja menoarvioesitykseen (perusaineistoineen) (Financial support given through taxing system, appendix No. 3 to the 1990 budget proposal of the state (with the basic data). Helsinki 1989 .

Uusitalo, Hannu (1988). Muuttuva tulonjako: hyvinvointivaltion ja yhteiskunnan rakennemuutosten vaikutukset tulonjakoon 1966-1985 (Changing income distribution: the influence of the welfare society and the structural changes of society on the income distribution 1966-1985). Tutkimuksia nro 148. Helsinki: Tilastokeskus.

Ministry of Finance, Planning Secretariat (1986-1989). Valtion menot kotitalouksien suoriin tulonsiirtoihin 1968 - 85 ja välillisiin tukiin eräiltä osin (Työryhmämuistio 1986: VM 8) sekä myöhempinä vuosina täydennetyt laskelmat (State expenditures on the direct income transfers of households 1968-85 and in some respects on indirect income subsidies (Working Group Memorandum 1986: VM 8) and calculations completed in later years). Helsinki: Valtiovarainministeriö, Suunnittelusihteeristö.

Ministry of Finance (1987). Sosiaalimenot ja kansantalous (Social expenditures and national economy). Työryhmämuistio 1987: VM 12). Helsinki: Valtiovarainministeriö.

Wright, Robert E. (1989). The Easterlin hypothesis and European fertility rates. Population and Development Review 15 (1): 107-122. 